\title{
Site-specific and integrated adaptation to climate change in the coastal mangrove zone of Soc Trang Province, Viet Nam
}

\author{
K. Schmitt • T. Albers • T. T. Pham • S. C. Dinh
}

Received: 20 February 2013 /Revised: 18 April 2013 /Accepted: 19 April 2013 /Published online: 16 May 2013

(C) The Author(s) 2013. This article is published with open access at Springerlink.com

\begin{abstract}
The dynamic coastline of Soc Trang Province in the Mekong Delta of Viet Nam is in most parts protected from erosion, storms and flooding by a narrow belt of mangroves. However, the unsustainable use of natural resources and development in the coastal zone is threatening the protection function of this forest belt. This situation is exacerbated by the impacts of climate change, particularly by the increased intensity and frequency of storms, floods and by rising sea levels. Based on analysis of past experience of mangrove planting and historical changes in mangrove cover, an integrated and site-specific approach to adaptation to climate change has been put in place, which comprises mangrove planting and rehabilitation with emphasis on resilience to climate change, and participatory involvement of local communities in effective mangrove management and protection through co-management. To address uncertainties associated with the impacts of climate change, testing of new mangrove planting techniques has started. This includes mimicking successful natural regeneration for small-scale planting in sites with high wave energy and transformation of existing even-aged plantations
\end{abstract}

\author{
K. Schmitt ( $\square)$ \\ Deutsche Gesellschaft für Internationale Zusammenarbeit (GIZ) \\ $\mathrm{GmbH}$, Soc Trang City, Viet Nam \\ e-mail: klaus.schmitt@giz.de \\ T. Albers \\ Engineering Consultants von Lieberman GmbH, Hamburg, \\ Germany \\ T. T. Pham \\ Southern Sub-institute of Forest Inventory and Planning, \\ Ho Chi Minh City, Viet Nam \\ S. C. Dinh \\ Southern Institute of Water Resources Research, \\ Ho Chi Minh City, Viet Nam
}

into more diverse forests - both in terms of structure and species composition. The pre-requisite for mangrove rehabilitation in erosion sites has successfully been put in place: breakwaters made from bamboo have reduced erosion and stimulated sedimentation. The design and construction of the wave-breaking structures, which was based on a numerical model which simulates hydrodynamics and shoreline development, ensures that downdrift erosion can be avoided as far as possible. A comprehensive monitoring program has been established and initial results provide evidence for the effectiveness of the bamboo breakwaters. Early experience shows that co-management is an effective way of maintaining and enhancing the protection function of the mangrove forest belt and at the same time providing livelihood for local communities. Payment for ecosystem services contributes to sustainability of co-management as well as livelihood improvement.

Keywords Climate change adaptation $\cdot$ Mangrove rehabilitation - Erosion protection · Co-management . Integrated coastal area management

\section{Introduction}

The Mekong Delta plays an important role as 'rice bowl' for the whole of Viet Nam. Rapid expansion of shrimp farming in the Mekong Delta has contributed to economic growth and poverty reduction, but has been accompanied by rising concerns over environmental and social impacts (Phan and Hoang 1993; de Graaf and Xuan 1998; Páez-Osuna 2001; Primavera 2006). Between 1987 and 1992 for example thousands of hectares of mangrove forest were converted into shrimp farms (Pham 2011). The lack of an integrated approach to sustainable management, utilization and protection of the coastal zone and economic interests in shrimp 
farming have led to the unsustainable use of natural resources, thus threatening the protection function of the mangrove forest belt and, in turn, reducing income for local communities. The coastal zone is also affected by the impacts of climate change (IPCC 2007; Carew-Reid 2007; MoNRE 2009; MRC 2009). Climate change is predicted to cause increased intensity and frequency of storms, floods and droughts, increased saline intrusion, higher rainfall during the rainy season and rising sea levels.

The project 'Management of Natural Resources in the Coastal Zone of Soc Trang Province, Viet Nam', which is funded by the German Federal Ministry of Economic Cooperation and Development and implemented by GIZ (Deutsche Gesellschaft für Internationale Zusammenarbeit), aims to protect and sustainably use the coastal wetlands for the benefit of the local population through mangrove rehabilitation and management with emphasis on resilience to climate change.

Soc Trang Province (Fig. 1) is one of 13 provinces in the Mekong Delta region and is located south of the Hau River, which is the southern-most arm of the Mekong. The province covers a total area of 331,176 ha, of which 205,748 ha are used for agriculture, 11,356 ha for forestry and 54,373 ha for aquaculture. The population of the province is $1,285,096$ out of which 371,266 are Khmer and 75,421 are ethnic Chinese (2008 figures from Soc Trang Statistics Office 2010). The coastal zone has a length of $72 \mathrm{~km}$.

The coastline of Soc Trang Province is characterized by a dynamic process of accretion and erosion created by the flow regime of the Mekong River and its sediment load, the tidal regime of the South China Sea (Vietnamese East Sea) and coastal long-shore currents driven by prevailing monsoon winds. In some areas of Soc Trang loss of land, due to erosion, of up to $30 \mathrm{~m}$ per year has been recorded, while in other areas land created through accretion can reach up to $64 \mathrm{~m}$ per year (Pham et al. 2009; Joffre 2010; Pham 2011). About $11 \mathrm{~km}$ of coast line of Soc Trang are currently subject to erosion. The earth dyke along this stretch of coast, which protects the hinterland from flooding, is in several places endangered by severe erosion, which in turn endangers the people and farmland directly behind the dyke. In several sites a total of around $300 \mathrm{~m}$ of mangrove forest in front of the dyke has been eroded away completely.

Along such a dynamic coastline a narrow mangrove forest belt is often not sufficient to protect the coast and the earth sea dyke from erosion. In such a setting mangrove management cannot be done effectively through a sectoral approach, it must be part of an integrated coastal area management (ICAM) approach which includes adaptation measures to climate change. ICAM requires risk management of the coastal zone

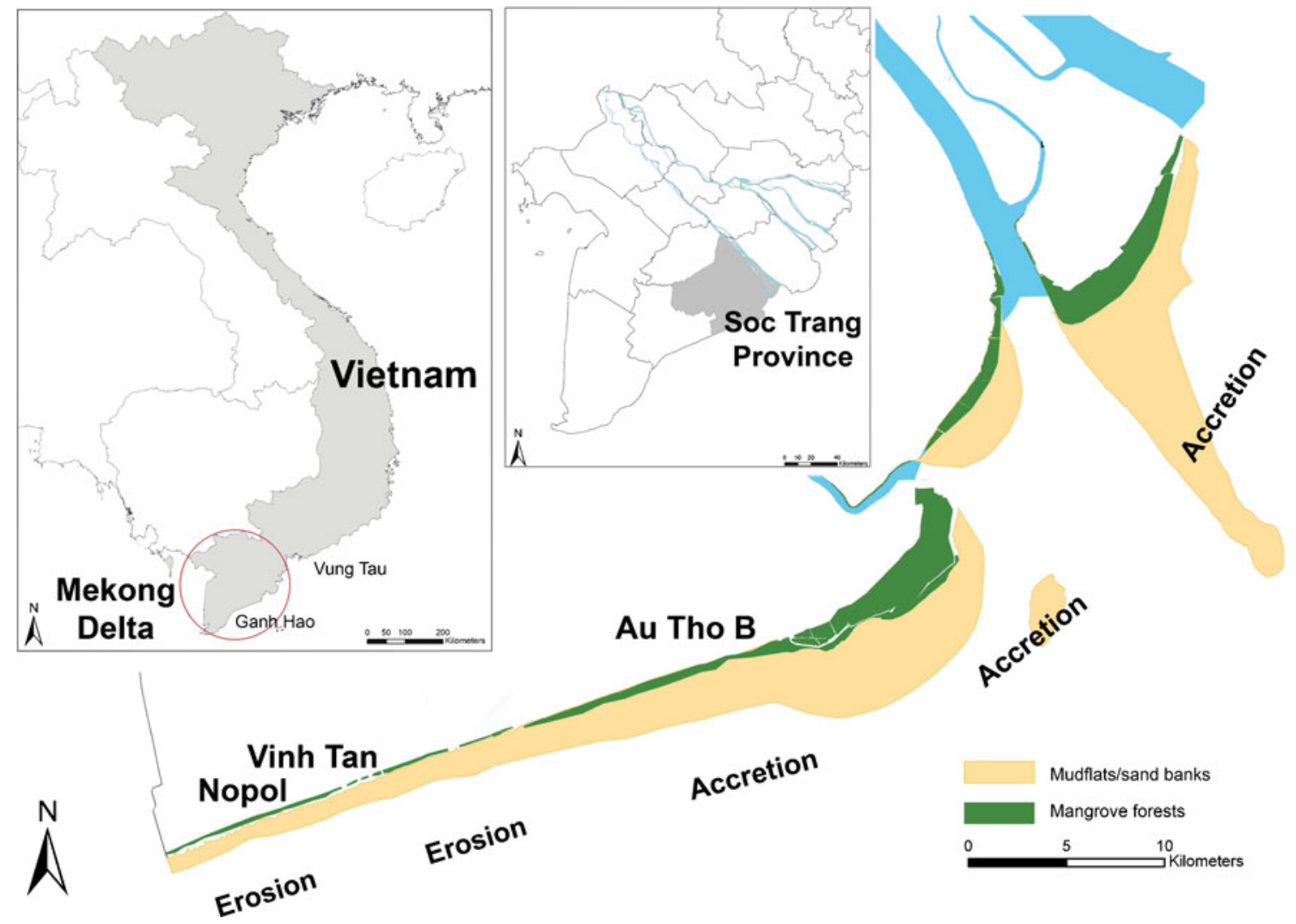

Fig. 1 Soc Trang Province, location of pilot sites and accretion/erosion areas. The accretion and erosion areas were determined by field work and reflect the current situation 
as a whole — not only of isolated erosion sites — by considering different options depending on site specific conditions and by putting in place risk spreading strategies over space and time to address uncertainties, such as dealing with predicted negative impacts of climate change. The project is therefore piloting new approaches to both mangrove rehabilitation/planting and to effective mangrove management and protection.

Mangroves provide a wide range of ecosystem services (Millennium Ecosystem Assessment 2005; Barbier 2007) including, in the context of climate change adaptation, protection of beaches and coastlines from storm surges, waves and floods; reduction of beach and soil erosion; stabilization of land by trapping sediments; and sequestration of carbon dioxide (Barbier 2007; Nagelkerken et al. 2008; Walters et al. 2008; McIvor et al. 2012).

Despite their importance mangroves have been degraded (over exploitation of coastal resources) and converted (landuse changes for agriculture, aquaculture and development) at a large scale (Alongi 2002; Giri et al. 2011). Between 1980 and 2005 about $20 \%$ of mangroves were lost, with Asia suffering the largest regional net loss (FAO 2007).

This widespread degradation and loss, together with an increasing awareness of the importance of these coastal forests, has led to many attempts to rehabilitate mangrove forests. The importance of identifying the main objectives of a restoration program and selecting species based on their autecology and community ecology, hydrological patterns, tidal amplitude, soil conditions, salinity and morphodynamics has been highlighted by many authors (e.g. Erftemeijer and Lewis 2000; Lewis 2001, 2005; 2009). This has also been shown by the analysis of success and failure of mangrove rehabilitation in Soc Trang between 1993 and 2008 (Pham 2011).

Mangrove forests can act as bioshields for the protection of people and assets from erosion and storms. Their effectiveness, however, depends on many variables and they do not provide effective protection against all hazards such as extremely large tsunami waves (Wolanski 2006; Mukherjee et al. 2010). Where bioshields are not likely to be effective, the choice is to retreat from the shoreline or to implement other forms of protection involving hard defenses (e.g. dykes) or a combination of hard and 'soft' interventions. Breakwaters can be used in specific sites to reduce erosion and stimulate sedimentation as a pre-requisite for mangrove rehabilitation.

When using mangroves for adaptation measures to the negative effects of climate change, it is essential to understand natural processes (Lewis 2005). This understanding will help with the design of appropriate, site-specific and integrated adaptation measures. Adaptation measures should include the testing of innovative approaches because we are dealing with uncertainties due to climate change and therefore need site-specific risk-spreading strategies over space and time.

All mangrove rehabilitation and planting efforts will be of little use if the plantations are not effectively protected afterwards. Newly planted forests must be protected from human impacts such as destructive fishing methods. In specific sites they must be protected from waves. Furthermore, established mangroves must be managed effectively and protected from human impact. To achieve this, the project introduced co-management, which has been used successfully for management of natural resources worldwide (Borrini-Feyerabend et al. 2004), as a new form of mangrove management in the pilot site of Au Tho B Village.

The main objective of mangrove rehabilitation in Soc Trang Province is coastal protection against tidal waters, erosion and storms. In order to achieve this in an effective way, the project is testing site-specific approaches for mangrove planting and rehabilitation with emphasis on resilience to climate change (innovative planting techniques which mimic natural regeneration and planting in erosion sites in combination with bamboo breakwaters), and the participatory involvement of local communities in effective mangrove management and protection through comanagement.

\section{Material and methods}

An overview of the methods and how they are linked to the outcomes is given in Fig. 2.

Assessment of past mangrove planting and rehabilitation experiences

Both for mangrove planting and rehabilitation, as well as effective mangrove protection and management, the project carried out systematic assessments of past experiences and an analysis of reasons for success or failure. These analyses were carried out by the Sub-institute of Forest Inventory and Planning, Ho Chi Minh City. Records from mangrove plantings since 1993 were compared with the results from field surveys (mangrove survival and growth rates) carried out in 2008. Additional information was obtained from a mangrove cover change analysis using topographic maps from archives and libraries in Aix en Provence and Paris (France) dating back to 1889 , aerial photos from 1953 to 1965, SPOT satellite images from 1995, Landsat ETM images from 2001 and QuickBird satellite images from 2006/7. The analysis of the effectiveness of mangrove protection and management was based on interviews with local people and local authorities.

Mangrove planting and rehabilitation

Mangrove planting trials which mimic natural regeneration were established and species, number, height and knots (the point on the stem where the opposite leaves are attached: 
Fig. 2 Schematic overview of the methods used and how they are linked to the outcomes (grey boxes). Monitoring is used to provide an evidence-base on the level of achievement of outcomes

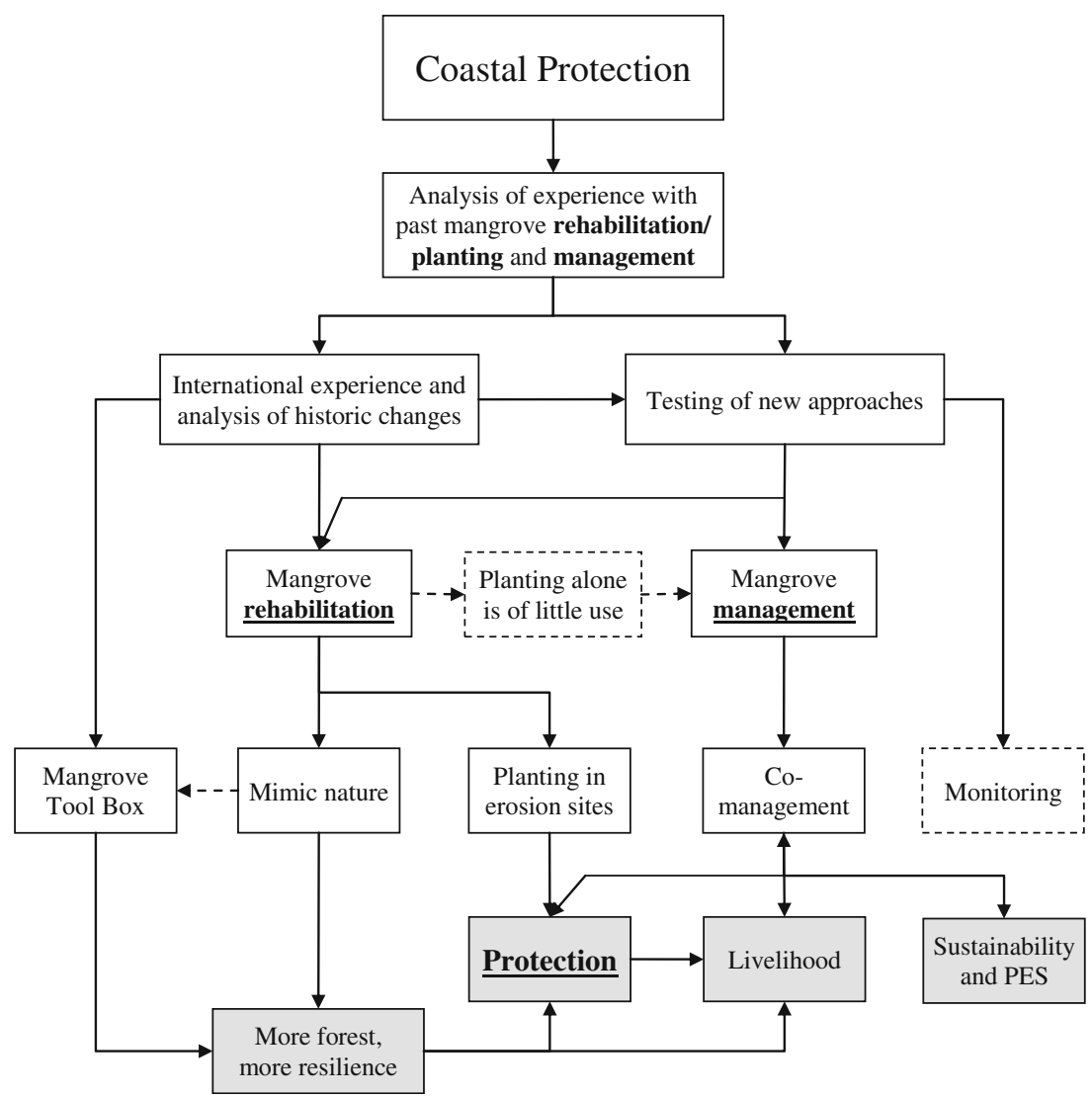

nodes) were recorded in randomly placed sampling plots as described in Pham et al. (2011).

One approach mimics natural regeneration of selected species by planting seedlings in high densities close to established trees and shrubs. This approach, which may achieve greater ecosystem resilience while maintaining the natural community structure and forest composition, may be suitable for small-scale planting in sites with high wave energy where patches of shrubs or mature trees are already established (Fig. 3a), because experience from many mangrove afforestation projects has shown that in such sites only seedlings planted close to mature trees survived (Duke, pers. comm.).

Twenty-four plots of around $30 \mathrm{~m}^{2}$ each (range 26$36 \mathrm{~m}^{2}$ ) were established on the seaward side of existing shrubby Rhizophora and Avicennia stands with an average height of 2-6 m. Seedlings were planted in October 2009 in densities ranging from 8 to 40 seedlings $/ \mathrm{m}^{2}$ and varying species compositions of Rhizophora apiculata and Ceriops tagal (Meinardi 2010). Additional planting of Avicennia marina was carried out in 18 plots in June 2010 with densities of 4-20 seedlings $/ \mathrm{m}^{2}$.

Percentage survival rates for Rhizophora apiculata and Ceriops tagal were recorded 4, 8, 16 and 33 months after planting. Results of the percentage survival rates per species and plot were grouped into 4 density classes with an average of 5.2, 9.1, 21.4 and 35 seedlings planted per square meter.
A second approach is the transformation of even-aged plantations into more diverse forests, both in terms of structure and species composition. This approach mimics the natural occurrence of canopy gaps and the natural regeneration which takes place in such gaps (Duke 2001).

Different gap sizes were created by felling 2, 3 or 4 mature trees in an even-aged, 13 year old Rhizophora plantation with an average height of 6-8 m, resulting in gaps from 7 to $45 \mathrm{~m}^{2}$ (Fig. 4a). Planting was carried out in 9 plots in October 2009, with a planting density of 21-46 seedlings $/ \mathrm{m}^{2}$ and a varying species composition of Rhizophora apiculata and Ceriops tagal. 9 gaps were left for natural regeneration to occur and 3 control plots without gaps were marked (Meinardi 2010). Additional planting of Avicennia marina was carried out in 9 plots in July 2011.

Percentage survival rates for Rhizophora apiculata and Ceriops tagal were recorded 4, 8, 16 and 28 months after the planting in canopy gaps with size groups of 13, 20, 22, 24, 31 and $38 \mathrm{~m}^{2}$.

\section{Erosion control}

Data on currents, waves, sediment concentrations and the bathymetry were recorded to improve the knowledge about hydrodynamic and morphodynamic processes and to generate input parameters for the numerical model. Three measuring campaigns were carried out which 
Fig. 3 Planting mangroves in high densities close to established shrubs (a) picture taken in $02 / 2010$, (b) same plot in $06 / 2012$
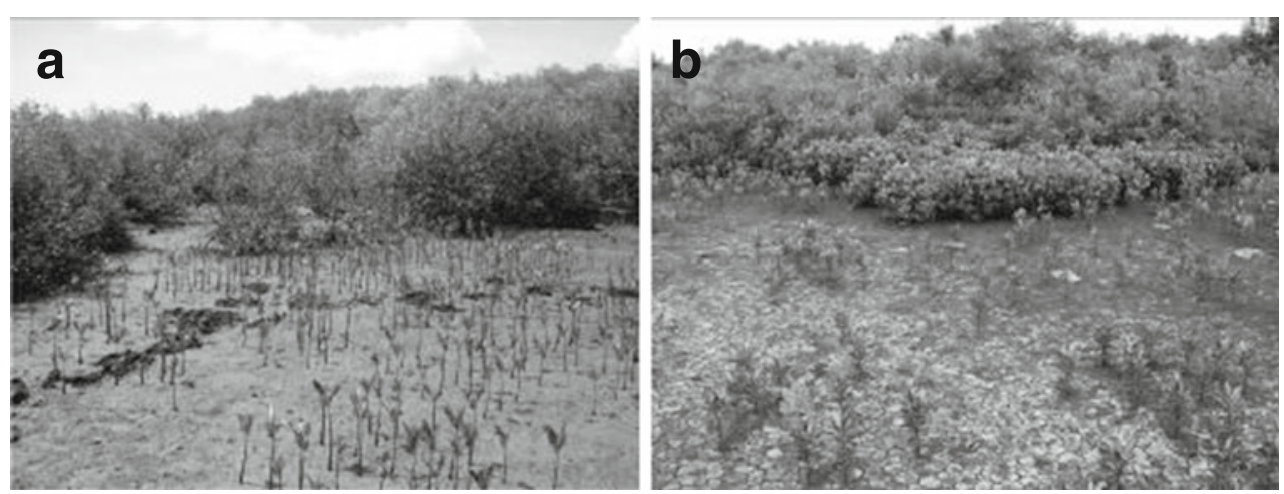

covered the northeast monsoon seasons (November to April) and southwest monsoon seasons (May to October). Vessel-based measurements of current parameters (velocity, direction) and bathymetry were carried out at 17 cross-shore profiles along a $20 \mathrm{~km}$ section of the coast of Vinh Tan Commune during different tidal phases. Sediment concentrations were measured along the cross-shore profiles in certain intervals. Selfsustaining sensors were used for stationary measurements of wave parameters, suspended sediment concentrations and current parameters in several positions near the endangered dyke at Vinh Tan. Data from the field measurements and available data on the bathymetry, water levels, river discharges and sediment loads were used to verify the results of the numerical modeling and to understand the hydrodynamic and morphodynamic processes in the focus area.

Hydrodynamic and morphodynamic models were developed for the design of wave-breaking barriers. An overview of the process is shown in Fig. 5. On the basis of the bathymetric data a two-dimensional depthaveraged numerical hydrodynamic model was set-up. For this, the Open Source Software RMA $\cdot$ KALYPSO was used (http://kalypso.bjoernsen.de), which consists of various sophisticated hydrological, hydraulic and damage modeling tools and modern decision support tools for spatial planning of flood risk management. The source code is a modified software distribution of the numerical model RMA-10S (King 2006, unpublished), which is based on RMA2 (Donnell et al. 2006). Further development of the model was carried out by the Institute of River and Coastal Engineering of the Hamburg University of Technology (Schrage et al. 2009). To design the breakwaters, information about the wave climate in the focus area was necessary. To obtain the wave parameters for different scenarios, the numerical wave model SWAN, which was integrated in RMA KALYPSO and was coupled with the hydrodynamic model was setup, calibrated and verified (www.swan.tudelft.nl). The results of the hydrodynamic modeling were used in the morphodynamic model GENESIS (Hanson and Kraus 1989) which simulated the shoreline changes in the focus area. Due to general uncertainties in morphodynamic modeling an evaluation and error estimation of the model results is crucial (Young et al. 1995).

The wave dampening effects of conventional breakwaters (rubble mounds) and adapted approaches using local materials (bamboo and brushwood) were tested in a wave flume. The wave dampening effects of bamboo fences were tested after construction in Vinh Tan. Waves were measured at two positions on the seaward and on the landward side of the bamboo fence each with a distance of approximately $5 \mathrm{~m}$ to the fence. For the measurements, pressure transducers were used. The measurements ran continuously for approximately 6 months
Fig. 4 Canopy gaps in Rhizophora plantation (a) small gap in $11 / 2009$, (b) much bigger natural gap 06/2012
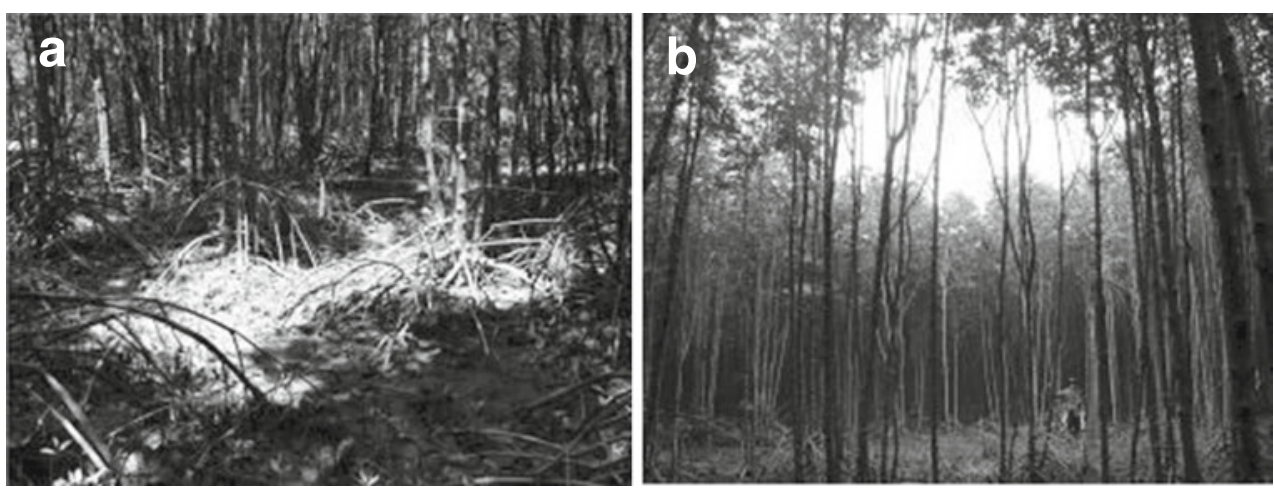
Fig. 5 Flow chart of the design process of the erosion protection (field measurements and available data were used to verify the models-dashed arrows)

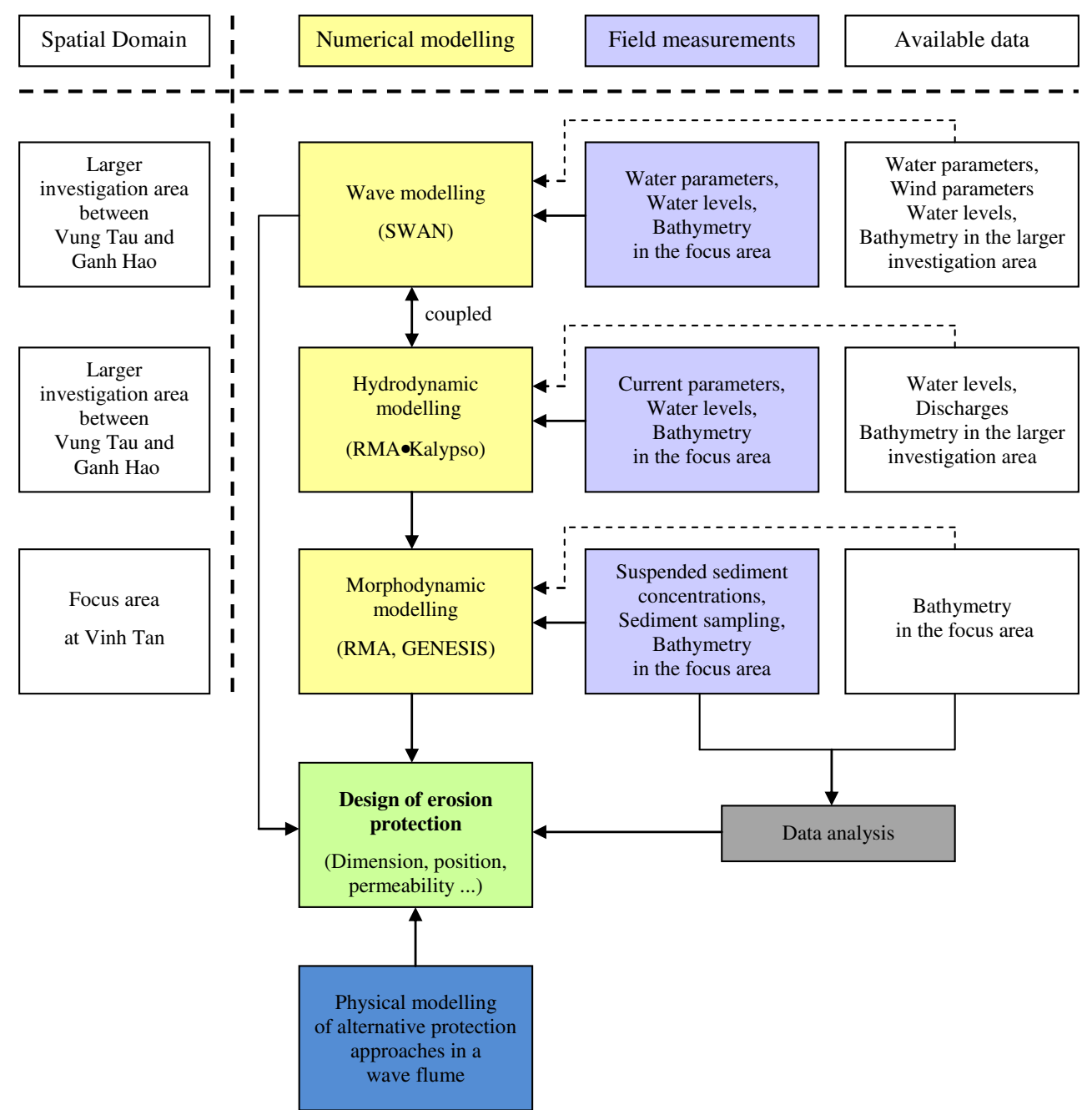

with a frequency of $10 \mathrm{~Hz}$. The wave data were analyzed and summarized in significant wave heights of 15 -min periods.

\section{Co-management}

For a new approach to effective mangrove protection and management through co-management, the project followed a 4-step participatory process. The steps are: (1) consultation and organisation - this step will end with the formal establishment of a resource user group; (2) a series of negotiation meetings which will end with a legal agreement between the local authorities and the resource users; (3) implementation of the agreement; and (4) monitoring and evaluation with emphasis on adaptive management (Lloyd 2010). These 4 steps are a different way of describing the 3 main phases of comanagement according to Borrini-Feyerabend et al. (2007).

\section{Results}

Dense planting close to established (mature) trees

For Rhizophora and Ceriops, results of a two-way ANOVA test indicate that there is a significant effect of planting density on the survival rate: $p=0.000689, \mathrm{df}=3$ for Rhizophora and $p=0.000357$ for Ceriops. Planting densities of 5 and 9 seedlings $/ \mathrm{m}^{2}$ were associated with significantly higher survival rates than planting densities of 21 and 35 seedlings $/ \mathrm{m}^{2}$.

There was a significant decline in survival of Rhizophora seedlings with time after planting $(p=0.020047, \mathrm{df}=3)$ while for Ceriops the decline was not significant $(p=$ 0.226579 ), with an average of $83.4 \%$ of seedlings still alive 33 months after planting.

Between February 2010 and June 2012, the average height increase for Ceriops was almost 5 fold and for Rhizophora almost 4 fold; after 3 years the average height 
for Rhizophora was $1.04 \mathrm{~m}$. Natural regeneration of Avicennia marina occurred sporadically.

Creating gaps for natural regeneration or planting

For Rhizophora and Ceriops results of a two-way ANOVA test showed that there was no effect of gap size on seedling survival ( $p=0.287625$ for Rhizophora and $p=0.137469$ for Ceriops, $\mathrm{df}=5)$.

There was a significant decline in survival over the 28 month period. After 16 months only a few Rhizophora seedlings were left in the gaps and after 28 months only one was left in a $24 \mathrm{~m}^{2}$ gap $(p=0.00000013, \mathrm{df}=3)$. The decline of Ceriops was slightly less marked, and after 28 months a few seedlings were still recorded in 3 plots and $27.6 \%$ of the originally planted seedlings had survived in a single $31 \mathrm{~m}^{2}$ plot $(p=0.0003152$ for Ceriops, $\mathrm{df}=3)$.

The nine gaps which were left for natural regeneration showed very little regeneration of Rhizophora (1 or 2 seedling in a few gaps) and no regeneration of Ceriops. After 16 months none of the naturally regenerated seedlings had survived. In the 3 control plots sporadic occurrence of a few seedlings was observed but none survived for more than a few months.

The average height of surviving Ceriops seedlings increased by $113.6 \%$ between February 2010 and February 2011. During the same period the average height of Rhizophora seedlings increased by $76.1 \%$. Between February 2011 and February 2012 the height increment was very small, but no analysis was carried due to the low number of plants still alive. The maximum height of Rhizophora after 2.5 years was $50 \mathrm{~cm}$.

\section{Mangrove rehabilitation/planting in erosion sites}

The recorded wave parameters showed a clear dependency on the monsoon season. Recorded currents showed a strong long-shore component due to the approaching tidal wave along the South Vietnamese coast. These currents were increased during the northeast monsoon season. The course of the suspended sediment concentration was affected by tidal currents, while the peaks of suspended sediment concentration were influenced by current velocities and wave heights. During flood tide, long-shore currents occurred at the same time as the peaks of the suspended sediment concentration. This indicates long-shore sediment transport, which reaches the highest values at the end of the rainy season (October/November) due to high sediment loads in the branches of the Mekong River. During the main period of the northeast monsoon, higher waves were recorded in the investigation area. The waves approached the coast of Soc Trang and Bac Lieu (south of Soc Trang Province) with a strong long-shore component. During this period, while the sediment plume of the Mekong is less pronounced and less material is available, the northeast monsoon winds cause increased coastal long-shore drift and erosion.

The numerical modeling was done in three steps (Fig. 5). A wave model was set up in a larger investigation area reaching from Vung Tau to Ganh Hao (distance about $250 \mathrm{~km}$ ) and $40 \mathrm{~km}$ out from the coast into the South China Sea. The results were used as design parameters for the erosion protection measures at the coast. The wave model was coupled with the hydrodynamic model which simulated currents and wave-induced currents. The results were then used as input parameters in the morphodynamic model which simulated the shoreline changes. This third model covered the coast around the focus area at Vinh Tan. It simulated shoreline changes based on the current and wave regime. Various structural (erosion protection) measures were integrated in the model and the resulting effects were simulated. The efficiency of the measures, the optimal positions and the best characteristic values were identified.

The results of both the field measurements and the numerical modeling were used to define important boundary conditions for the design of countermeasures: soft soil with silty and clayey material; significant wave heights of $0.65 \mathrm{~m}$; wave periods between $5 \mathrm{~s}$ and $6 \mathrm{~s}$; tidal range of $3.50 \mathrm{~m}$; water depths at dyke up to $2 \mathrm{~m}$ at high water.

Six months of wave height measurements offer representative results for the wave damping effect of the bamboo fences in various wave and tidal conditions. The reduction of the wave height, and thus the effectiveness of the bamboo fence, very much depends on the wave parameters of the incoming waves and the tidal conditions. Figure 6 shows the wave dampening effect in percent of incoming waves independent from the actual wave height, both for the results of the field measurements and the results of the physical modeling. On the $y$-axis the wave transmission coefficient $\mathrm{k}_{\mathrm{T}}$ is displayed (ratio between the transmitted wave height $\left(\mathrm{H}_{\mathrm{T}}\right)$ on the landward side and the initial wave height $(\mathrm{H})$ on the seaward side). A transmission coefficient of 0.3 therefore means that the transmitted wave height $\mathrm{H}_{\mathrm{T}}$ is $30 \%$ of the initial wave height $\mathrm{H}$, and the reduction of the wave height is $70 \%$. On the $\mathrm{x}$-axis the influences of the tidal conditions (the water level) and the characteristics of the approaching waves (explicit the wave height and implicit the wave length) are considered and combined in one coefficient. The freeboard $R_{C}$ is the distance from the top of the structure to the water surface and thus indicates the water level in relation to the bamboo fence. A negative freeboard indicates a submerged crest, e.g. when the water level is above the bamboo fence, and so does a negative coefficient $\mathrm{R}_{\mathrm{C}} / \mathrm{H}$. Furthermore, in this coefficient the initial wave height $\mathrm{H}$ is considered. The wave length, which is also important for the effectiveness of the structure, is considered implicitly in the water depths. 
Fig. 6 Wave transmission coefficients derived from physical modeling and field measurements

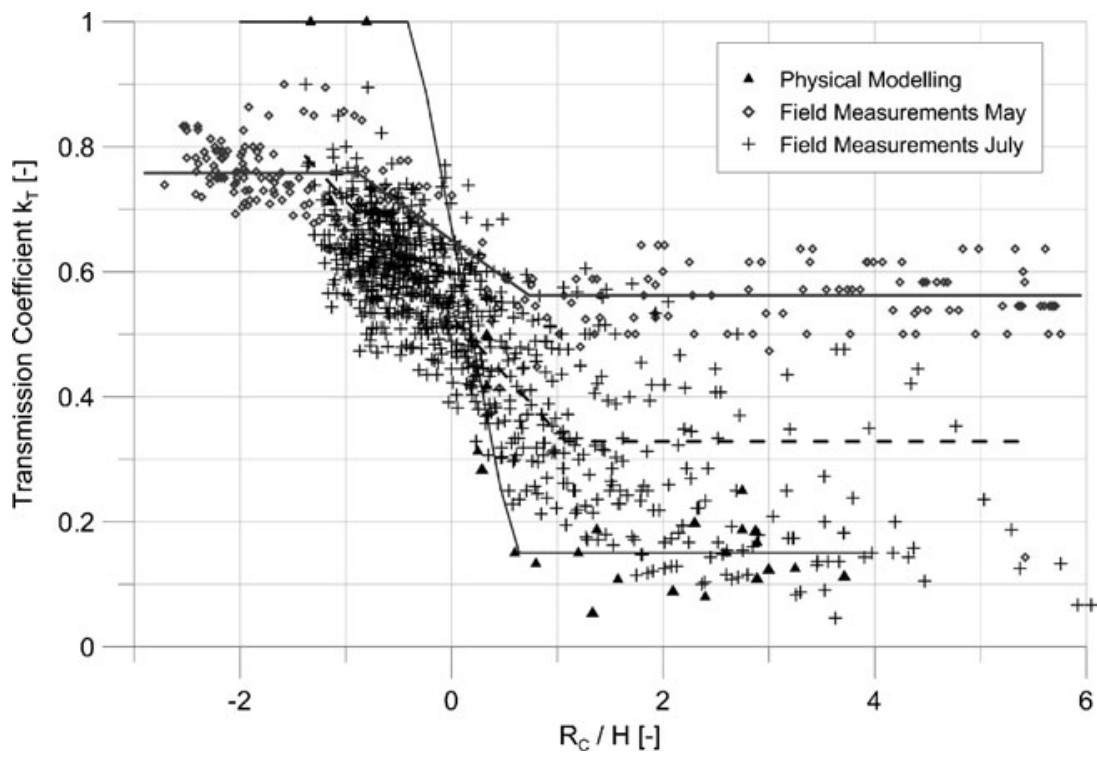

The black triangles in Fig. 6 show the results of the physical modeling in a wave flume with a fence with two rows of bamboo and a filling of brushwood. At a ratio $\mathrm{R}_{\mathrm{C}} / \mathrm{H}$ of approximately 0.6 the transmitted wave height is only $15 \%$ of the initial wave height. For higher submergences or larger wave heights the transmission coefficient becomes 1.0. The continuous thin black line is the best-fit through the measured values.

The transmission coefficient derived from the field measurement is approximately 0.75 when the water level is above the crest of the bamboo fence $\left(\mathrm{R}_{\mathrm{C}} / \mathrm{H}<0\right)$, which means a reduction of the initial wave height of $25 \%$. When the water level drops below the crest of the bamboo fence $\left(\mathrm{R}_{\mathrm{C}} / \mathrm{H}>0\right)$, the transmission coefficient is between 0.60 and 0.20 depending on the structure of the brushwood bundles. Flexible bundles lead to smaller wave transmission coefficients (black crosses) than stiff bundles (black rhombi) and thus have a larger wave damping effect which can reach up to $80 \%$ reduction of the initial wave height. The dashed line and the thick black line are lines of best-fit through the measured values.

The wave transmission coefficients derived from the physical modeling are smaller because the poles of the bamboo fences in the physical model were placed closer together than in the fences constructed in Vinh Tan. Here, the bamboo poles where placed with a gap of $0.30 \mathrm{~m}$. This wider spacing was implemented during field testing were the design of the model was optimized under consideration of static design aspects and due to economic reasons.

Bamboo fences yielded very good results in the field testing and have additional advantages due to the strength, local availability and low cost of bamboo. Experiences from 10 years of use of bamboo in erosion protection in Khok Kha (Samut Sakhon Province, Thailand) showed that bamboo used for wave-breaking barriers lasts for 5-7 years (pers. comm. Worapol Douglomchan 2011). The fences are constructed by two rows of bamboo poles with several layers of bundles in between. Normally, the top of the construction is equal to the mean high water level.

In many places along the east coast of Soc Trang Province, remaining headlands with mangrove vegetation are interrupted by gaps where floodplains are eroded and the waves directly reach the dyke. Closing these gaps will create a smooth shoreline with contour lines more or less parallel to the coast. Here, cross-shore and longshore bamboo fences are used to form fields approximately $50 \mathrm{~m} \times$ $50 \mathrm{~m}$ in size, where currents and waves are damped and deposition of sediments is supported. The cross-shore fences decrease the longshore currents and the longshore fences damp the incoming wave energy. The fences parallel to the shoreline have openings $20 \mathrm{~m}$ in width to secure the drainage of the fields (Fig. 7).

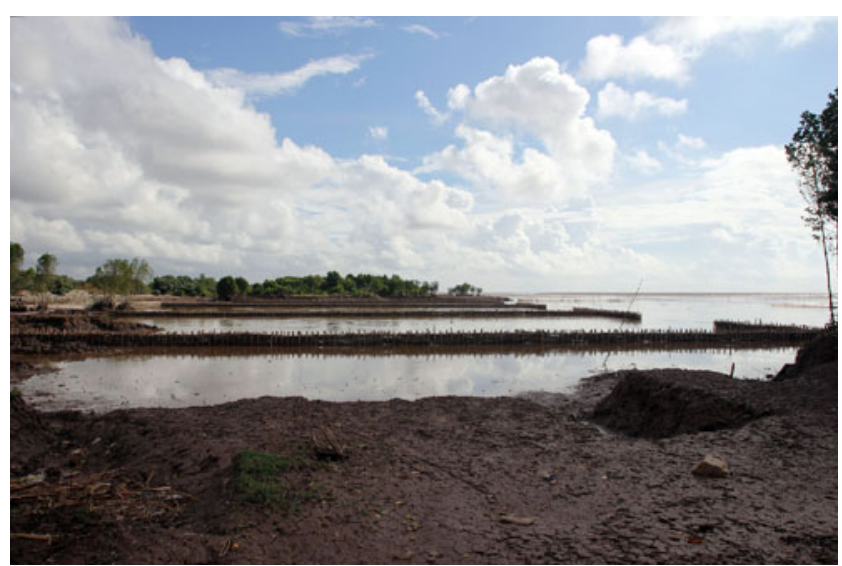

Fig. 7 T-shaped arrangement of bamboo fences as a measure of floodplain management 
Effective mangrove management and protection through co-management

The co-management process followed in Au Tho B Village has been described in detail by Lloyd (2010). During this participatory process resource users and local authorities jointly negotiate a formal agreement on their respective roles, responsibilities and rights, and formed a pluralistic governance body (Borrini-Feyerabend 2011). The result in $\mathrm{Au}$ Tho $\mathrm{B}$ is effective protection of the mangrove forest belt, improved livelihood for local communities, and better governance (Schmitt 2012).

\section{Discussion}

Decisions made now about climate change adaptation measures which focus on a single strategy, rather than a diverse suite of adaptation strategies, may lead to path dependencies and ultimately to a reduction in adaptive capacity. Individual adaptation options which are developed in isolation, with inconsistent strategies and without a vision of a preferred future may create adaptation conflicts and lead to maladaptations, or path dependencies (Smith et al. 2013).

When addressing climate change and adaptation we are dealing with uncertainty. It is therefore important not to put all efforts in a single adaptation strategy, but to focus on ecosystem-based approaches which address diversity, connectivity, and adaptive capacity (Bernhardt and Leslie 2013). Adaptation measures often address climate variability rather than climate change. This provides the opportunity to test a diverse suite of innovative measures - and after their effectiveness has been evaluated - the successful measures can then be applied if, when and where needed. This can ensure adaptive capacity in future while at the same time urgent measures of adaptation to climate variability can be put in place now.

In the case of the Mekong Delta there is a strong focus on protective strategies such as dyke building, planting of an at least $500 \mathrm{~m}$-wide mangrove belt in front of the dyke and forest protection contracts for individual households. It is, however, important to put in place site-specific adaptation measures which are suitable across the range of ecological conditions and socio-ecological dynamics found along the coast of Soc Trang following an ecosystem-based approach which addresses diversity, connectivity, and adaptive capacity. This becomes even more important when looking at extended time frames in the context of climate change. Bernhardt and Leslie (2013) also emphasise that traditional management strategies, which are often sector or species specific, cannot effectively deal with the effects of climate change.

Strategies for coastal protection can be grouped into defence (hold the line), retreat, expansion, adaptation and do nothing. Static engineered response to shoreline protection using sea dykes should not be the only adaptation approach. More diverse strategies offer greater opportunities for switching between strategies and ensuring less dependence on a single strategy. "There are no absolute rules, nor absolute solutions to the problem of coastal erosion given the dynamic and the diverse character of the shoreline. No single set of regulations, or single land use management philosophy, is appropriate for all coastal situations or settings. The diversity of the coasts requires consideration of a variety of solutions when addressing problems in a particular area." (CEM 2002, page I-2-16).

In sites, where a concrete dyke is the appropriate solution, care must be taken to design the dyke in such a way that it can be raised in response to sea level rise when needed. There is no need to build dykes now which are high enough for a predicted sea level rise of $1.0 \mathrm{~m}$ by 2100 . However, the dyke crest for example must be wide enough for the dyke to be heighten when needed while maintaining a seaward slope of 1:6 or even flatter.

An earth dyke is often sufficient in sites where mangroves can grow because a healthy mangrove forest will protect the dyke from erosion. The effect of mangroves on coastline protection in Viet Nam has been demonstrated by Mazda et al. (1997) who showed that a $1.5 \mathrm{~km}$ wide belt of 6 year old mangroves reduced the height of incoming waves from $1.0 \mathrm{~m}$ to $5 \mathrm{~cm}$ (at the coastline/dyke). In areas without mangroves the waves were reduced to $75 \mathrm{~cm}$ in height, due to bottom friction. This has also clear financial benefits. US\$1.1 million invested in mangrove rehabilitation in northern Viet Nam saved US\$7.3 million annually for dyke maintenance (Brown et al. 2006).

In sites where erosion has destroyed the mangrove forest, rehabilitation can only succeed if wave energy is reduced and sedimentation stimulated (Chong 2005; Fröhle et al. 2008, Zemlys et al. 2007) because mangroves grow only along sheltered tropical and sub-tropical coastlines (FAO 1994). They do not grow naturally in sites with strong erosion. In such sites, an erosion control model is needed which combines 'hard' and 'soft' solutions, i.e. breakwaters and mangroves. Care must be taken to design structural measures so that they avoid negative effects such as downdrift erosion as far as possible (Kamphuis 2010). This can be achieved through the use of T-fences which connect existing headlands, close eroded gaps in the mangrove forest belt and recreate eroded floodplains. The use of fences for land reclamation started on the German North Sea coast around the year 1365 after several severe storm surges caused large losses of land on the coasts. In 1847, systematic land reclamation was established by the Danish government (Probst 1996). Until the middle of the 20th century, the aim of land reclamation was to create new fertile areas for agricultural cultivation, but during the last three decades, 
land reclamation has been used as an active measure aimed at coastal protection (Kramer 1989). Using the same principles along the Mekong Delta coast in Vinh Tan and Nopol has shown that bamboo T-fences are a successful measure of coastal protection in specific sites.

Planting of an at least $500 \mathrm{~m}$-wide mangrove belt in front of the dyke is a strategy which cannot be applied in every site. Mangroves only grow in sites with the right hydrological patterns, tidal amplitude, soil conditions, salinity and morphodynamics. In addition, information about historic distribution of mangrove species contributes to a better understanding of their habitat requirements and dynamics (Joffre 2010). In the case of Soc Trang, the importance of appropriate species selection, site selection for the planting of different species, planting techniques and the best planting times has been described in a mangrove planting and management tool box consisting of three manuals: Mangrove Nursery (Hoang and Pham 2010); Mangrove Planting and Management (Pham et al. 2009) and Monitoring (Pham et al. 2011). The mangrove planting manual also covers examples of new approaches for mangrove planting.

First analysis of the planting trial which mimics nature by planting seedlings in high densities close to established trees and shrubs showed that planting densities of 5 to 9 seedlings $/ \mathrm{m}^{2}$ were associated with better survival than higher planting densities. If this kind of small-scale planting is expanded, after 2 years it can lead to a tapering forest edge (Fig. 3b).

The seedling survival rate over time showed some decline for Rhizophora and no significant decline for Ceriops. However, seedling survival may not be the best indicator for the success of mangrove rehabilitation. Monitoring which aims to provide evidence about success of mangrove rehabilitation should focus on mangrove forest health rather than species survival rate.

Analysis of the data from the trial which used artificial canopy gaps to examine whether planting in these gaps or natural regeneration will contribute to transforming evenaged plantations into more diverse forests showed that there was no effect of gap size on seedling survival for gaps between 13 and $38 \mathrm{~m}^{2}$ for seedlings planted and up to $45 \mathrm{~m}^{2}$ for natural regeneration. In all plots seedling decline was significant and 28 month after planting most of the planted seedlings and all the naturally regenerated seedlings had died.

Survival of seedlings may be influenced by the extensive use of the area for collection of natural resources, particularly firewood, as well as other environmental factors and crabs which destroy seedlings. However, the fact that successful natural regeneration occurred in a much bigger natural gap near the artificially created gaps (Fig. 4b) is an indication that the limited availability of light may be the main factor contributing to the low survival rate and rapid decline in seedling numbers. One could hypothesize that a gap size of $45 \mathrm{~m}^{2}$ is too small to successfully support natural regeneration or survival of planted seedlings. Further studies will be required to verify this hypothesis.

An adaptation strategy should not only focus on planting mangroves, it should also aim to maintain the health of the remaining mangrove ecosystems effectively, and it should reduce the rate of mangrove loss. This is often more effective than trying to plant new mangrove forests. The health of existing forests can for example be improved by converting monospecific plantations into more resilient forests. Mangrove loss and degradation of mangrove health can also be avoided through awareness-raising and by putting in place effective management structures.

Analyses of successes and failures of mangrove management approaches in Soc Trang have shown that individual household-based forest protection contracts did not work and were financially unsustainable (Joffre and Luu 2007; Pham 2011). This is supported by Sikor and Nguyen (2011) who concluded that transfer of tenure to communities possesses little value if forest protection obligations are more important than rights to forest management. In such a situation comanagement offers an effective solution. Co-management is placed in between full control by a state government (such as a National Park managed by a state authority) on one side and full control by local actors on the other side (see table 3 page 27, Dudley 2008). In co-management of mangrove protection forests on the sea-side of the dyke the land is owned by the government while the decision-making power, management responsibility and accountability are shared between government agencies and local communities who depend on the natural resources for their livelihood. The importance of shared governance between the actors has been highlighted by Borrini-Feyerabend (2011).

More than 3 years of experience with mangrove comanagement in $\mathrm{Au}$ Tho $\mathrm{B}$ Village has shown that comanagement is an effective way of maintaining and enhancing the protection function of the mangrove forest belt and, at the same time, providing livelihoods for poor local people. This has been confirmed through resource-use monitoring and by people who are using resources from the mangrove forest for their livelihood and as a result of comanagement have more income, better governance and more resources. The increase in aquatic resources is the result of the sustainable use of resources from the mangrove forests and the exclusion of resource-use in the protection zone (Schmitt 2012). An increase of aquatic resources through exclusion of use in defined areas has also been shown by Laegdsgaard and Johnson (1995), Mumby et al. (2004) and Mumby (2006).

Through the co-management process, the local resource users have been organized into a group recognized by law and negotiated a co-management agreement jointly with the 
relevant local authorities. Through this agreement and its resource-use regulations the resource users are given clear and secure user rights to sustainably use resources as well as the responsibility to manage the resources sustainably and to protect the mangrove forests. This increases the sense of ownership and results in improved and more effective protection of the resources, which has also been shown for Indonesia by Erdman et al. (2004). Locally made rules and regulations, which are the result of a participatory process, contribute to high compliance. This is supported by findings from Cinner et al. (2005) for marine protected areas. Ownership by all stakeholders involved in joint governance, or co-management, is a key factor for success, as is political support. In the case of Viet Nam, support from the Provincial People's Committee is a prerequisite for the successful implementation of co-management. Champions who are prepared to support innovative ideas and can motivate others are also essential for the success of co-management.

Co-management should be part of an integrated coastal management strategy which looks at the coastal zone as a whole and which considers different management options depending on site specific and socio-economic conditions. This includes other land/resource-uses or controls in the vicinity and their interactions with co-management. One example is commercial farming of clams on sandbanks in front of the co-managed mangrove forest. Here it is essential to look at how people access the sandbanks through the forest and that stakeholders in charge of clam farming are involved in the co-management process and access planning.

Mangrove co-management, in contrast to community forestry which focuses on silviculture (and where the government's role is often that of a technical advisor, not a joint decision-maker), is primarily done with the aim of protection, and thus resource-use is restricted. Resource users therefore have only limited options for getting direct financial benefits from the co-management of mangroves, although they and others benefit from the ecosystem services provided by effectively managed and protected mangrove forests. These include storm, flood and erosion protection for all people living in the coastal zone as well as food, shelter and nursery ground for aquatic species, which benefits all who catch aquatic resources (Hamilton and Snedaker 1984; Schatz 1991; Samonte-Tan et al. 2007; Aburto-Oropeza et al. 2008; Warren-Rhodes et al. 2011).

To ensure sustainability of mangrove protection through co-management, the project initiated a payment for ecosystem services involving the private sector. After a long consultation process with all stakeholders, the members of the clam cooperative on the sand banks in front of the mangrove forests of $\mathrm{Au}$ Tho B agreed that they will benefit from a well-protected and managed mangrove forest through higher clam yields. Based on this, a direct payment from the clam cooperative to the co-management group was negotiated. The clam cooperative will pay for the operational costs of mangrove comanagement - and this has been written into the statute of the cooperative. Furthermore, by joining the clam cooperative, members of the mangrove co-management group receive direct financial benefits, which are related to the condition of the mangrove forest and their efforts to protect it.

In the case of $\mathrm{Au}$ Tho $\mathrm{B}$, payment for mangrove ecosystem services through reimbursement of operational costs is a direct payment which can be implemented based on the acceptance by users and providers of the service without the need for valuation of the services provided by mangroves. This is another example where different site specific and appropriate solutions are put in place as part of an integrated approach.

\section{Conclusions}

Climate change adaptation measures must be based on a sound understanding of natural processes, such as shoreline changes induced by erosion and accretion. This is particularly important along the highly dynamic coast of the Mekong Delta where site-specific adaptation measures are needed. Adaptation measures must be part of an integrated approach to coastal area management which also considers human activities along the coast, because they often exacerbate coastal erosion. They should also include testing of innovative approaches because of uncertainties due to climate change. This requires putting in place risk-spreading strategies over space and time. A viable adaptation strategy should include a diverse and site-specific range of approaches to ensure that adaptation conflicts, maladaptations, or path dependencies can be avoided.

The understanding of natural processes has contributed to the development of site- and species-specific mangrove planting recommendations in a comprehensive manual. The trialing of innovative planting techniques which mimic nature has produced some initial results: small-scale plantings with densities of 5 to 9 seedlings $/ \mathrm{m}^{2}$ close to established trees and shrubs showed high survival rates and expansion of such plantings after 2 years formed a tapering forest edge. This creates a forest structure which is close to that of a natural forest. Forest structure and biodiversity can be used as indicators for the success of mangrove rehabilitation.

The development of an erosion control model has started which combines bamboo wavebreakers designed according to computer-based current and erosion modeling, and mangrove rehabilitation. The careful design of erosion protection measures, which will minimize damage in other places, requires field measurements and numerical modeling as well as appropriate design of the actual protection measures. 
Testing of co-management for mangrove protection and management has shown very promising results in Au Tho B Village. Co-management can clearly maintain and enhance the protection function of the mangrove forest belt while at the same time provide livelihood for local communities. The set-up of a pluralistic governance body for joint decisionmaking and the involvement of the private sector through payment for ecosystem services contribute to sustainability.

Open Access This article is distributed under the terms of the Creative Commons Attribution License which permits any use, distribution, and reproduction in any medium, provided the original author(s) and the source are credited.

\section{References}

Aburto-Oropeza O, Ezcurra E, Danemann G, Valdez V, Murray J, Sala E (2008) Mangroves in the Gulf of California increase fishery yields. Proc Natl Acad Sci 105(30):10456-10459

Alongi DM (2002) Present state and future of the world's mangrove forests. Environ Conserv 29(3):331-349

Barbier EB (2007) Valuing ecosystem services as productive inputs. Econ Policy 22:177-229

Bernhardt JR, Leslie HM (2013) Resilience to Climate Change in Coastal Marine Ecosystems. Annual Review of Marine Science. 5:371-392 http://www.annualreviews.org/doi/pdf/10.1146/ annurev-marine-121211-172411. Accessed 30 Jan 2013

Borrini-Feyerabend G (2011) Keynote Paper: Co-management and shared governance - the "Effective and Equitable Option" for Natural Resources and Protected Areas? In: Spelchan DG, Nicoll IA, Nguyen TPH (eds) Co-management/Shared Governance of Natural Resources and Protected Areas in Viet Nam. Proceedings of the National Workshop on Co-management Concept and Practice in Viet Nam, Soc Trang, 17-19 March 2010. Deutsche Gesellschaft für Internationale Zusammenarbeit (GIZ) GmbH, Management of Natural Resources in the Coastal Zone of Soc Trang Province, Vietnam, pp 5-25. http://czm-soctrang.org.vn/en/ Publications.aspx. Accessed 30 Jan 2013

Borrini-Feyerabend G, Pimbert M, Farvar MT, Kothari A, Renard Y (2004) Sharing power. Learning by doing in co-management of natural resources throughout the world. IIED and IUCN/CEESP/ CMWG, Cenesta

Borrini-Feyerabend G, Farvar MT, Nguinguiri JC, Ndangang VA (2007) Comanagement of natural resources: Organising, negotiating and learning-by-doing. GTZ and IUCN, Kasparek Verlag, Heidelberg, Revised reprint of the 2000 publication

Brown O, Crawford A, Hammill A (2006) Natural disasters and resource rights: Building resilience, rebuilding lives. International Institute for Sustainable Development, Manitoba

Carew-Reid J (2007) Rapid assessment of the extent and impact of sea level rise in Viet Nam. Climate change discussion paper 1. ICEM International Centre for Environmental Management, Brisbane

CEM (2002) Coastal Engineering Manual. US Army Corps of Engineers, Coastal \& Hydraulics Laboratory. http://chl.erdc.usace.army.mil/ chl.aspx?p=s\&a=ARTICLES;104. Accessed 30 Jan 2013

Chong J (2005) Protective values of mangroves and coral ecosystem: A review of methods and evidence. IUCN pp 1-5 http://cmsdata.iucn.org/ downloads/pr_values_mangrove_coral_ecosystems_methods evidence.pdf. Accessed 30 Jan 2013

Cinner J, Marnane MJ, McClanahan TR, Almany GR (2005) Periodic closures as adaptive coral reef management in the indo-Pacific.
Ecol Soc 11(1):31. http://www.ecologyandsociety.org/vol11/iss1/ art31/ES-2005-1618.pdf. Accessed 30 Jan 2013

de Graaf GJ, Xuan TT (1998) Extensive shrimp farming, mangrove clearance and marine fisheries in the Southern Provinces of Vietnam. Mangroves Salt Marshes 2:159-166

Donnell BP, Letter JV, McAnally WH (2006) Users Guide for RMA2 Version 4.5. U.S. Army, Engineer Research and Development Center, Valhalla

Dudley N (ed) (2008) Guidelines for Applying Protected Area Management Categories. IUCN WCPA, Gland (Switzerland). 86 pp. http://data.iucn.org/dbtw-wpd/edocs/PAPS-016.pdf. Accessed 30 Jan 2013

Duke NC (2001) Gap creation and regenerative processes driving diversity and structure of mangrove ecosystems. Wetl Ecol Manag 9:257-269

Erdman MV, Merrill PR, Mongdong M, Arsyad I, Harahap Z, Pangalila R, Elverawati R, Baworo P (2004) Building Effective Co-management Systems for Decentralized Protected Areas Management in Indonesia: Bunaken National Park Case Study. Natural Resources Management Program. Jakarta. http://www.irgltd.com/Resources/Publications/ANE/200405\%20Bunaken\%20National\%20Park.pdf. Accessed 30 Jan 2013

Erftemeijer PLA, Lewis RR (2000) Planting Mangroves on Intertidal Mudflats: Habitat Restoration or Habitat Conversion? In: Proceedings of the ECOTONE VIIIth Seminar, Enhancing Coastal Ecosystem Restoration for the 21st Century. Bangkok: Royal Forest Department, pp 156-165

FAO (1994) Mangrove forest management guidelines. FAO Forestry Paper No. 117. Rome, Italy. http://ia700404.us.archive.org/2/items/ mangroveforestma $034845 \mathrm{mbp} /$ mangroveforestma034845mbp.pdf. Accessed 30 Jan 2013

FAO (2007) The world's mangroves 1980-2005. FAO Forestry Paper 153, Rome, Italy. ftp://ftp.fao.org/docrep/fao/010/a1427e/ a1427e00.pdf. Accessed 30 Jan 2013

Fröhle P, Zemlys P, Davuliene L, Gulbinskas S (2008) Numerical simulation of sediment transport as one basis for the assessment of coastal protection measures in Palanga, Lithuania. In: Galappatti R, van Schel L, Al Maidoor E, Al Zahed K, Wens F, Scheffer H, Brüh H, Mocke G (eds) Best practices in the coastal environment. Proceedings of the 7th International Conference on Coastal and Port Engineering in Developing Countries (PIANCCOPEDEC VII), on CD-ROM, PIANC, Dubai, UAE, Paper No 164

Giri C, Ochieng E, Tieszen LL, Zhu Z, Singh A, Loveland T, Masek J, Duke N (2011) Status and distribution of mangrove forests of the world using earth observation satellite data. Glob Ecol Biogeogr 20(1):154-159

Hamilton LS, Snedaker SC (eds) (1984) Handbook for mangrove area management. Environment and Policy Institute, East-west Center; IUCN, UNESCO, UNDP, Honolulu

Hanson H, Kraus NC (1989) GENESIS: Generalized model for simulating shoreline change, report 1: Technical reference. Tech. Rep. CERC-89-19. U.S. Army Engineer Waterways Experiment Station, Coastal Engineering Research Center, Vicksburg

Hoang VT, Pham TT (2010) Mangrove Nursery Manual. Deutsche Gesellschaft für Technische Zusammenarbeit (GTZ) GmbH, Management of Natural Resources in the Coastal Zone of Soc Trang Province, Vietnam. http://czm-soctrang.org.vn/en/ Publications.aspx. Accessed 30 Jan 2013

IPCC (2007) Climate Change 2007: Synthesis Report. Summary for Policymakers. Intergovernmental Panel on Climate Change (IPCC). http://www.ipcc.ch/pdf/assessmentreport/ar4/syr/ar4 syr_spm.pdf. Accessed 30 Jan 2013

Joffre O (2010) Mangrove Dynamics in Soc Trang Province 1889-1965. Deutsche Gesellschaft für Technische Zusammenarbeit (GTZ) 
$\mathrm{GmbH}$, Management of Natural Resources in the Coastal Zone of Soc Trang Province, Vietnam. http://czm-soctrang.org.vn/en/ Publications.aspx. Accessed 30 Jan 2013

Joffre O, Luu HT (2007) A Baseline Survey in the Coastal Zone of Soc Trang Province, Livelihood Assessment and Stakeholder Analysis. Management of Natural Resources in the Coastal Zone of Soc Trang Province. Deutsche Gesellschaft für Technische Zusammenarbeit (GTZ) GmbH. http://czm-soctrang.org.vn/en/Publications.aspx. Accessed 30 Jan 2013

Kamphuis JW (2010) Introduction to Coastal Engineering and Management. Advanced Series on Ocean Engineering-Vol. 16. World Scientific, pp 525

Kramer J (1989) Kein Deich, kein Land, kein Leben - Geschichte des Küstenschutzes an der Nordsee. Verlag Gerhard Rautenberg, Leer (in German)

Laegdsgaard P, Johnson CR (1995) Mangrove habitats as nurseries: unique assemblages of juvenile fish in subtropical mangroves in eastern Australia. Mar Ecol Prog Ser 126:67-81

Lewis RR (2001) Mangrove restoration - costs and benefits of successful ecological restoration. Submitted for publication. Proceedings of the mangrove valuation workshop, Universiti Sans Malaysia, Penang, April 4-8, 2001. Beijer International Institute of Ecological Economics, Stockholm

Lewis RR (2005) Ecological engineering for successful management and restoration of mangrove forests. Ecol Eng 24:403-418

Lewis RR (2009) Methods and Criteria for Successful Mangrove Forest Restoration pp. 787-800. In: Perillo GME, Wolanski E, Cahoon DR, Brinson MM (eds) Coastal Wetlands: An Integrated Ecosystem Approach. Elsevier Press, pp 941

Lloyd R (2010) Co-management in Au Tho B Village: A pilot Test for the Coastal Zone of Soc Trang Province. Deutsche Gesellschaft für Technische Zusammenarbeit (GTZ) GmbH, Management of Natural Resources in the Coastal Zone of Soc Trang Province, Vietnam. http://czm-soctrang.org.vn/en/Publications.aspx. Accessed 30 Jan 2013

Mazda Y, Magi M, Kogo M, Hong PN (1997) Mangroves as a coastal protection from waves in the Tong King Delta, Vietnam. Mangroves Salt Marshes 1:127-135

McIvor AL, Möller I, Spencer T, Spalding M (2012) Reduction of wind and swell waves by mangroves. Natural Coastal Protection Series: Report 1. Cambridge Coastal Research Unit Working Paper 40. Published by The Nature Conservancy and Wetlands International. $27 \mathrm{pp}$. http://coastalresilience.org/sites/default/files/resources/ McIvor\%20et $\% 20$ al $\% 202012 \% 20$ Reduction $\% 20$ of $\% 20$ wind $\% 20$ and $\% 20$ swell $\% 20$ waves $\% 20$ by $\% 20$ mangroves $\% 20$ TNC $\% 20$ Report.pdf. Accessed 30 Jan 2013

Meinardi D (2010) Development of a Comprehensive Mangrove Monitoring System in the Mekong Delta, Viet Nam. Master of Science Thesis in Water Resources Management in Tropical and Subtropical Regions Suderburg, Germany. http://czm-soctrang.org.vn/en/ Publications.aspx. Accessed 30 Jan 2013

Millennium Ecosystem Assessment (2005) Ecosystems and human well-being: Wetlands and water synthesis. World Resources Institute, Washington, DC

MoNRE (2009) Climate change, Sea level rise scenarios for Vietnam. Ministry of Natural Resources and Environment, Hanoi

MRC (2009) Adaptation to climate change in the countries of the lower Mekong basin: Regional synthesis report. MRC technical paper No. 24. Mekong River Commission, Vientiane

Mukherjee N, Dahdouh-Guebas F, Kapoor V, Arthur R, Koedam N, Sridhar A, Shanker K (2010) From bathymetry to bioshields: a review of post-tsunami ecological research in India and its implications for policy. Environ Manag 46(3):329-339

Mumby PJ (2006) Connectivity of reef fish between mangroves and coral reefs: algorithms for the design of marine reserves at seascape scales. Biol Conserv 128:215-222
Mumby PJ, Edwards AJ, Arias-González JE, Lindeman KC, Blackwell PG, Gall A, Gorczynska MI, Harborne AR, Pescod CL, Renken H, Wabnitz CCC, Llewellyn G (2004) Mangroves enhance the biomass of coral reef fish communities in the Caribbean. Nature 427:533-536

Nagelkerken I, Blaber S, Bouillon S, Green P, Haywood M, Kirton LG, Meynecke J-O, Pawlik J, Penrose HM, Sasekumar A, Somerfield PJ (2008) The habitat function of mangroves for terrestrial and marina fauna: a review. Aquat Bot 89(2):155185

Páez-Osuna F (2001) The environmental impact of shrimp aquaculture: causes, effects, and mitigating alternatives. Environ Manag 28(1):131-140

Pham TT (2011) Mangroves of Soc Trang 1965-2007. Deutsche Gesellschaft für Internationale Zusammenarbeit (GIZ) $\mathrm{GmbH}$, Management of Natural Resources in the Coastal Zone of Soc Trang Province, Vietnam. http://czm-soctrang.org.vn/en/ Publications.aspx. Accessed 30 Jan 2013

Pham TT, Hoang T, Tran HM, Le Trong H, Schmitt K (2009) Tool Box for Mangrove Rehabilitation and Management. Deutsche Gesellschaft für Technische Zusammenarbeit (GTZ) GmbH, Management of Natural Resources in the Coastal Zone of Soc Trang Province, Vietnam. http://czm-soctrang.org.vn/en/Publications.aspx. Accessed 30 Jan 2013

Pham TT, Meinardi D, Schmitt K (2011) Monitoring of Mangrove Forests. Deutsche Gesellschaft für Internationale Zusammenarbeit (GIZ) $\mathrm{GmbH}$, Management of Natural Resources in the Coastal Zone of Soc Trang Province, Vietnam. http://czm-soctrang.org.vn/en/ Publications.aspx. Accessed 30 Jan 2013

Phan NH, Hoang TS (1993) Mangroves of Vietnam. IUCN Bangkok, Thailand

Primavera JH (2006) Overcoming the impacts of the aquaculture on the coastal zone. Ocean Coast Manag 49:531-545

Probst B (1996) Deichvorlandbewirtschaftung im Wandel der Zeit. In: Kuratorium für Forschung im Küsteningenieurwesen (ed) Die Küste, Heft 58, vol 58. Boyens Verlag, Heide, in German

Samonte-Tan GPB, White AT, Tercero MA, Diviva J, Tabara E, Caballes C (2007) Economic valuation of coastal and marine resources: Bohol marine triangle, Philippines. Coast Manag 35(2):319-333

Schatz RE (1991) Economic Rent Study for the Philippine Fisheries Sector Program. Asian Development Bank Technical Assistance 1208, Philippines, Manila, pp 42

Schmitt K (2012) Mangrove planting, community participation and integrated management in Soc Trang Province, Viet Nam. In: Macinthosh DJ, Mahindapala R, Markopoulos M (eds): Sharing lessons on mangrove restoration. Bangkok, Thailand: Mangroves for the Future and Gland, Switzerland: IUCN: 205-225. http://mangrovesforthefuture.org/assets/Repository/Documents/ Call-for-Action-and-Proceedings-from-2012-ColloquiumMamallapuram-India.pdf. Accessed 30 Jan 2013

Schrage N, Antanaskovic D, Jung T, Pasche E (2009) KALYPSO-An Open Source Software Tool for Flood Studies in Rivers of the 8. International Conference on Hydroinformatics, Concepción (Chile). Curran Associates, Inc., pp 1058-1067

Sikor T, Nguyen QT (eds.) (2011) Realizing Forest Rights in Vietnam: Addressing Issues in Community Forest Management. RECOFTC The Center for People and Forests, Bangkok, Thailand. 59 pp. http://dl.is.vnu.edu.vn/bitstream/123456789/392/1/ AF574d01.pdf. Accessed 30 Jan 2013

Smith TF, Thomsen DC, Gould S, Schmitt K, Schlegel B (2013) Cumulative pressures on sustainable livelihoods: coastal adaptation in the Mekong Delta. Sustainability 5(1): 228241 http://www.mdpi.com/2071-1050/5/1/228/pdf. Accessed 30 Jan 2013 
Soc Trang Statistics Office (2010) Soc Trang Statistical Yearbook 2009. Statistical Publishing House, Hanoi, Vietnam. Translated from: C c Th ng Kê T nh Sóc Trăng (2010) Niên Giám Th ng Kê T nh Sóc Trăng Năm 2009. Nhà Xu t B n Th ng Kê, Hà N i, Vi t Nam, pp 419

Walters BB, Rönnbäck P, Kovacs J, Crona B, Hussain SA, Badola R, Primavera J, Barbier EB, Dahdouh-Guebas F (2008) Ethnobiology, Socio-Economics and management of mangrove forests: a review. Aquat Bot 89(2):220-236

Warren-Rhodes K, Schwarz A-M, Boyle L, Albert J, Suti Agalo S, Warren R, Bana A, Paul C, Kodosiku R, Bosma W, Yee D, Rönnbäck P, Crona B, Duke N (2011) Mangrove ecosystem services and the potential for carbon revenue programmes in Solomon Islands. Environ Conserv 38(4):485-496
Wolanski E (2006) Synthesis of the protective functions of coastal forests and trees against natural hazards. In: Braatz S, Fortuna S, Broadhead J, Leslie R (eds) Coastal protection in the aftermath of the Indian ocean tsunami: What role for forests and trees? Proceedings of the Regional Technical Workshop. FAO, Khao Lak, pp 161-183

Young RS, Pilkey OH, Bush DM, Thieler ER (1995) A discussion of the generalized model for simulating shoreline change (GENESIS). J Coastal Res 11:875-886

Zemlys P, Fröhle P, Gulbinskas S, Davulienė L (2007) Near-shore evolution model for Palanga area: feasibility study of beach erosion management. Geologija 57: 45-54. http:/www.lmaleidykla.lt/ojs/ index.php/geologija/article/view/1486/503. Accessed 30 Jan 2013 